\title{
Palynology of a terrestrial coal-bearing series across the Triassic/Jurassic boundary (Mecsek Mts, Hungary)
}

\section{Katrin Ruckwied}

Shell International Exploration and Production, Rijswijk

József Pálfy

Hungarian Academy of Sciences - Hungarian Natural History Museum, Research Group for Paleontology, Budapest
Annette E. Götz

Darmstadt University of Technology, Institute of

Applied Geosciences, Darmstadt

Ákos Török

Department of Construction Materials and Engineering Geology, Budapest University of Technology and Economics, Budapest

Palynology and palynofacies patterns of terrestrial Triassic/Jurassic boundary series of the South Hungarian Mecsek Mountains were studied in search of paleoenvironmental and vegetation changes and climatic signatures related to one of the major mass extinction events in Earth's history. Two selected and studied boreholes comprise continuous boundary sections and yield a diverse Late Rhaetian to Hettangian palynomorph assemblage. The most striking feature within the boundary interval is the series of cyclic short-term paleoenvironmental changes from fluvial/deltaic to swamp settings, as inferred from changes in palynomorph associations. However, increasing humidity is documented by a striking increase in trilete spores. These signatures display the response of terrestrial vegetation to regional and global environmental changes, although we found no clear evidence for a mass extinction as documented in the microflora.

Key words: palynology, palynofacies, Triassic/Jurassic boundary, climatic change, NW Tethyan realm, Mecsek Mountains, South Hungary

\section{Introduction}

Complete terrestrial Triassic/Jurassic boundary series are rare (e.g. Olsen et al. 2002; Voigt et al. 2006; Hornung et al. 2007); in the NW Tethyan realm, the Mecsek Mountains of South Hungary is the only area where continuous sections of coalbearing facies are present. Pécs and Komló were the two regional centers of coal mining (Fig. 1), which was terminated in 2003. Previously the Pécs coal pit

Addresses: K. Ruckwied: Kessler Park 1, NL-2288 GS Rijswijk, The Netherlands

A. E. Götz: Schnittspahnstr. 9, D-64287 Darmstadt, Germany

J. Pálfy: H-1431 Budapest, P.O. Box 137, Hungary

Á. Török: H-1521 Budapest, Sztoczek u. 2, Hungary

Received: March 20, 2008; accepted: May 23, 2008 


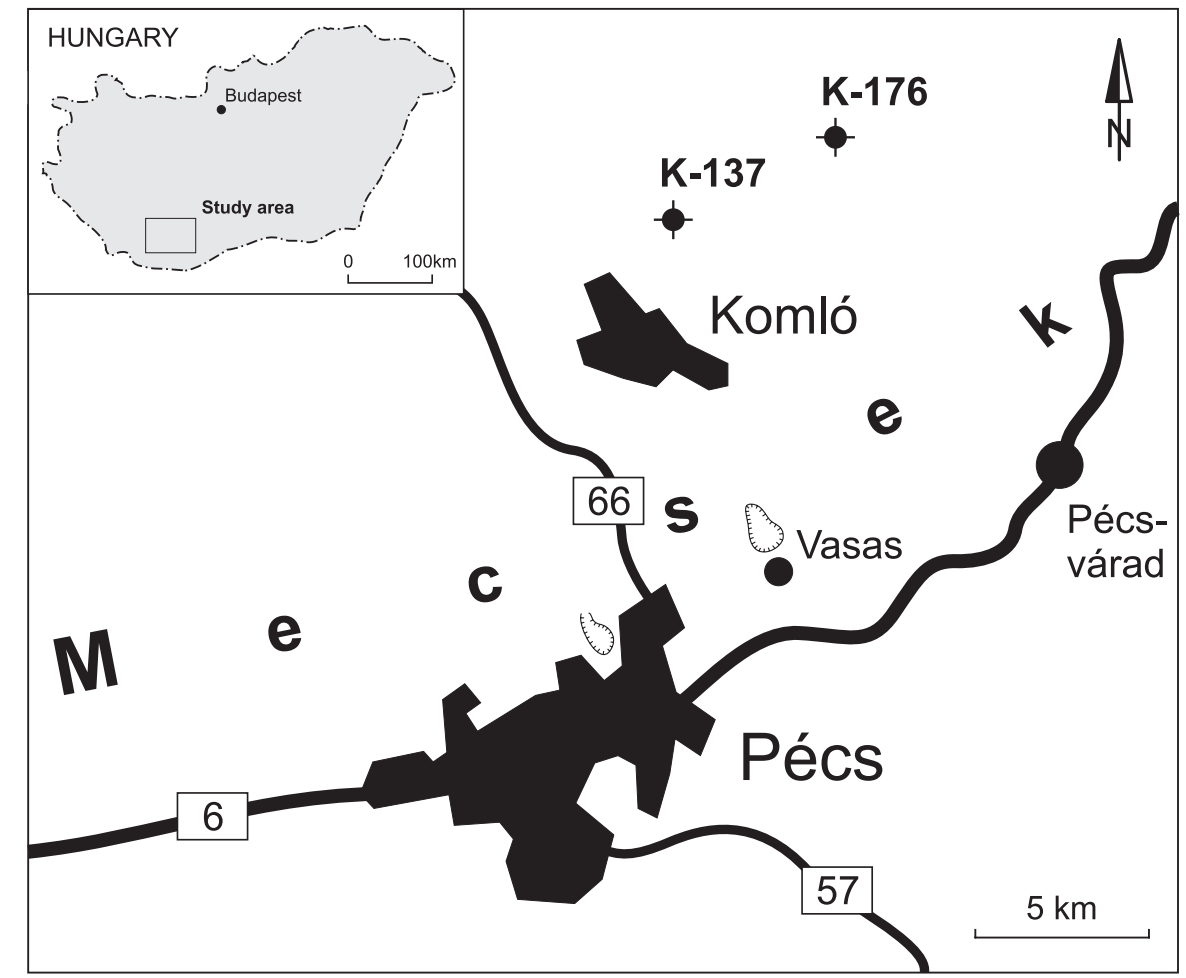

Fig. 1

Location of the studied boreholes Komló K-137 and K-176, Mecsek Mts. (South Hungary)

provided an excellent exposure of the Rhaetian-Hettangian series, but its lower part is flooded now. However, due to the intensive mining activities in this region during the second half of the 20th century, a significant number of coal exploration wells were drilled and documented. Most of the data are only listed in internal reports (in Hungarian) and are not available in scientific journals. Much information, however, is summarized in a volume (published in Hungarian) devoted to the exploration and mining geology of the Mecsek Coal (Némedi Varga 1995). Detailed stratigraphic description of the coal-bearing series and discussion of placement of the Triassic/Jurassic boundary are provided by Nagy and Nagy (1969), Nagy (1971) and Némedi Varga (1983, 1998). Palynological investigations were mainly carried out during the 1960's and 1970's with special focus on commercial mining, and principally aimed at correlation of distinct coal seams (e.g. Bóna 1963, 1969, 1979, 1983, 1995a, b). A paleoenvironmental model of shallow and deeper swamp zones, distinguished primarily on the basis of palynological observations including the conifer pollen to spore ratio, was developed by Bóna (1963). A detailed palynofacies analysis focusing paleoenvironmental and climatic signatures is addressed for the first time in the 
present study. Our results contribute to the discussion on changes of vegetation within global mass extinction events (e.g. McElwain and Punyasena 2007; McElwain et al. 2007).

\section{Geologic setting}

During Late Triassic and Early Jurassic times the study area was located on the northern Tethyan shelf margin E of the Bohemian Massif and Vindelician High (Fig. 2), bordering the Neotethys Ocean Branch (Haas 2004). The Mecsek Mountains are part of the Tisza Mega-unit, subdivided into the Mecsek, VillányBihor, Papuk-Békés-Lower Codru, and N-Backa-Upper Codru (Biharia) facies zones (Bleahu et al. 1994). These zones underwent Alpine tectonic deformation, forming NE-SW-striking nappe-systems which are the basement of Tertiary basins in central and southern Hungary, northern Serbia and western Romania. Triassic and Jurassic outcrops are restricted to the Mecsek and Villány mountains in Hungary, the Papuk Mountains and adjacent hills in Croatia, and the Apuseni Mountains in Romania (Bleahu et al. 1994).

Facies differentiation characterizes the Late Triassic evolution of the Tisza Mega-unit dominated by dolomite (western Mecsek Mts, Villány Mts, Codru and

Fig. 2

Paleogeography of the NW Tethyan realm during the Late Triassic (Rhaetian) and location of the Mecsek Mts. (MM) as part of the Tisza Mega-unit (after Haas 2004)

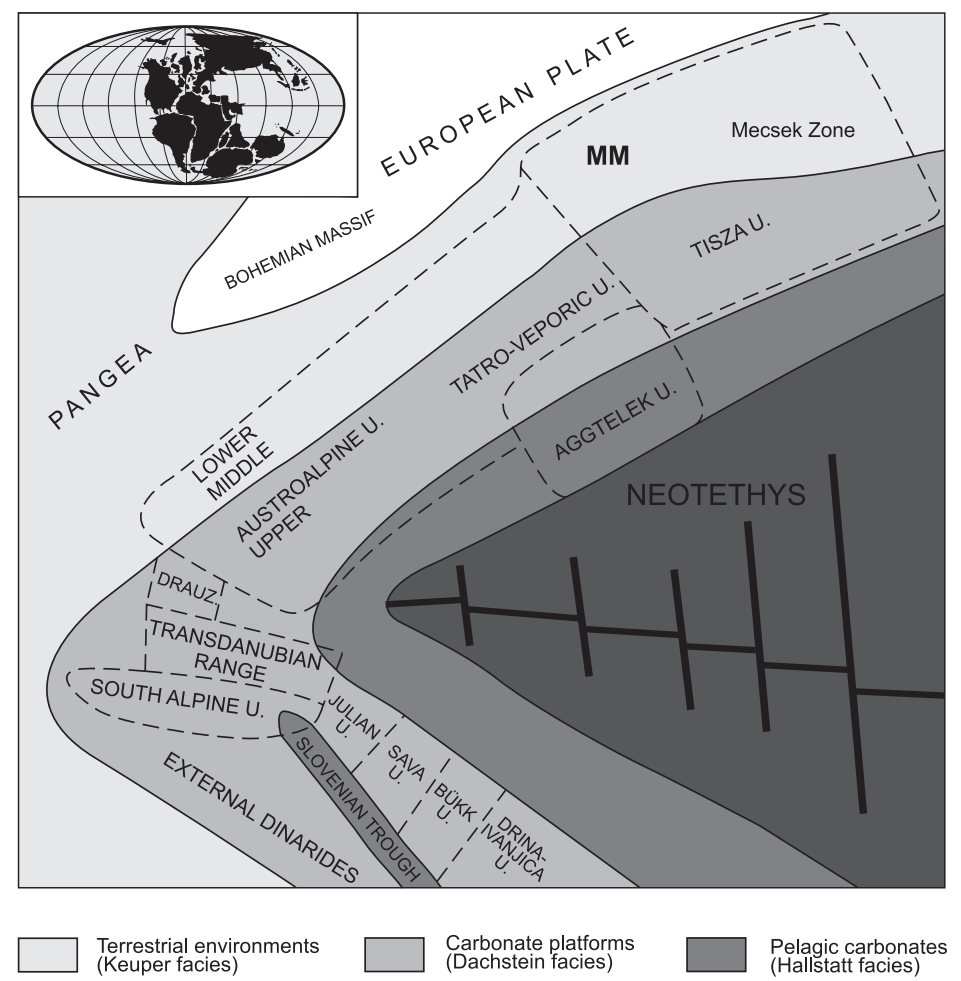


Papuk Mts), siliciclastics (eastern Mecsek Mts) and mixed carbonate-siliciclastic sequences (Bihor Mts), all of which are similar both to the Germanic and to the Carpathian Keuper (Haas and Török 2008). A rapidly subsiding half-graben structure developed in the eastern Mecsek Mountains, resulting in the formation of up to $500 \mathrm{~m}$ of arkosic sandstone and siltstone (Karolinavölgy Sandstone Formation). Its depositional environments include marginal marine, lagoonal, and deltaic to lacustrine settings (Nagy 1968). The upward transition of these beds into the Jurassic coal-bearing succession (Mecsek Coal Formation) is continuous. The first coal layers already appear in the Upper Rhaetian Karolinavölgy Sandstone. Upsection, coal seams become thicker and more frequent and are a characteristic feature of the Hettangian deposits (Mecsek Coal Formation). Marine ingressions occurred sporadically from the Late Hettangian into the Early Sinemurian. Deposition of the overlying, fully marine Vasas Marl Formation began in the Late Sinemurian, showing transitional features between the Alpine Gresten facies and "Fleckenmergel".

\section{Material and methods}

The cores selected for study from the Komló area are from boreholes K-137 (drilled in 1960) and K-176 (drilled in 1972). Both were part of the exploration program of the Hungarian coal-mining industry and are reference sections of the geology of the area. The cores were studied palynologically by József Bóna (cf. Bóna 1995b). Unfortunately, a large part of the cores is no longer available. Reports on the cores and Bóna's palynological slides are kept in the Central Geoscience Data Archive in Budapest and the Natural History Collections of Komló, respectively. Bóna's palynological slides of the Komló K-176 core were restudied and some of the palynological residue kept in the Komló collections was mounted for new slides. The Triassic/Jurassic boundary interval from core K137 was sampled in the Pécs-Vasas Core Repository of the Hungarian Geological Institute. The lithology of the Komló cores was documented by Gy. Hônig (unpublished internal reports 1960, 1972; in Hungarian), who described a sedimentary series of fine-grained sandstone and siltstone with intercalated thin coal layers, becoming more frequent upsection. Within the Triassic/Jurassic boundary interval the average thickness of the coal seams is $0.5 \mathrm{~m}$.

Palynofacies analysis was carried out on a total of 42 samples from the Upper Rhaetian and Lower Hettangian series of the Komló boreholes K-176 and K-137, comprising sandstones, siltstones, and coal seams. All samples were prepared using standard palynological processing techniques, including $\mathrm{HCl}(33 \%)$ and $\mathrm{HF}$ (73\%) treatment for dissolution of carbonates and silicates, and saturated $\mathrm{ZnCl}_{2}$ solution $(\mathrm{D} \approx 2.2 \mathrm{~g} / \mathrm{ml})$ for density separation. Residues were sieved at $15 \mu \mathrm{m}$ mesh size. Slides were mounted in Eukitt, a commercial, resin-based mounting medium. The relative percentages of sedimentary organic constituents are based on counting at least 500 particles per slide. The classification of sedimentary organic particles follows Steffen and Gorin (1993). 
The Sporomorph Ecogroup Model (SEG model) of Abbink et al. (2001, 2004a) has been applied to the Komló data set. Originally, this ecogroup model was defined for the Late Jurassic and Early Cretaceous of the North Sea. In this study, it is applied for the first time to Rhaetian and Hettangian assemblages. The SEG model is based on the assumption that palynomorph assemblages reflect mother plant communities. In the Mesozoic, any application of paleocommunity models is considerably hampered by uncertainties with respect to the botanical affinities of quantitatively important sporomorphs and the ecological preference of the extinct parent plants. However, based on actualistic principles, one may assume the presence of distinctive habitat-controlled paleocommunity types, each of which is characterized by taxa with broadly similar ecological preferences. These paleocommunity types serve as a paleoecological framework for the conceptual Sporomorph Ecogroup Model of coexisting sources of dispersed spores and pollen grains. Abbink et al. (2001) defines six SEGs as presented in Table 1.

Table 1

Sporomorph ecogroups after Abbink et al. (2001)

\begin{tabular}{|l|l|l|}
\hline SEG & Reflection & Description \\
\hline Upland SEG & upland communities & $\begin{array}{l}\text { vegetation on higher terrain well above } \\
\text { groundwater level that is never submerged by } \\
\text { water }\end{array}$ \\
\hline River SEG & lowland communities & $\begin{array}{l}\text { vegetation on plains and/or in freshwater } \\
\text { swamps; the plains may periodically be } \\
\text { submerged by freshwater; there is no influence } \\
\text { of sea salt; except, perhaps, under extreme } \\
\text { circumstances }\end{array}$ \\
\hline Pioneer SEG & riverbank communities & $\begin{array}{l}\text { vegetation on riverbanks which are } \\
\text { periodically submerged and subject to erosion }\end{array}$ \\
\hline Coastal SEG & $\begin{array}{l}\text { vegetation at unstable and recently developed } \\
\text { ecospace, e.g. vegetation growing at places } \\
\text { that had been submerged by the sea for a } \\
\text { longer period }\end{array}$ \\
\hline Tidally influenced SEG & $\begin{array}{l}\text { tidally influenced } \\
\text { communities }\end{array}$ & $\begin{array}{l}\text { vegetation growing immediately along the } \\
\text { coast, never submerged by the sea but under a } \\
\text { constant influence of salt spray }\end{array}$ \\
\hline
\end{tabular}

\section{Palynofacies patterns}

The palynofacies of the studied core material is dominated by phytoclasts, showing a high variability in size and shape. Most of the particles are opaque fragments; however, translucent plant debris is also documented. The palynomorph assemblage of the Upper Rhaetian part of the sections is dominated by bisaccate pollen grains, trilete spores and pollen of the Circumpolles group, comprising a small amount of Corollina spp. Upsection, a striking increase of 


\section{K. Ruckwied et al.}

trilete spores is recognized (Fig. 3). Another prominent feature within the palynomorph assemblage is the sudden increase of Dictyophyllum harrisii within the Triassic/Jurassic boundary interval, followed by a peak abundance of Inaperturopollenites sp. This signal is repeated upsection in a cyclic pattern (Fig. 4). Within the sedimentary series two main microfloral assemblages are distinguished: Assemblage A, dominated by Inaperturopollenites sp. and characteristic of coal layers, and assemblage B, mainly composed of trilete spores and bisaccate pollen grains, characteristic of sandstone and siltstone layers (Fig. 5).

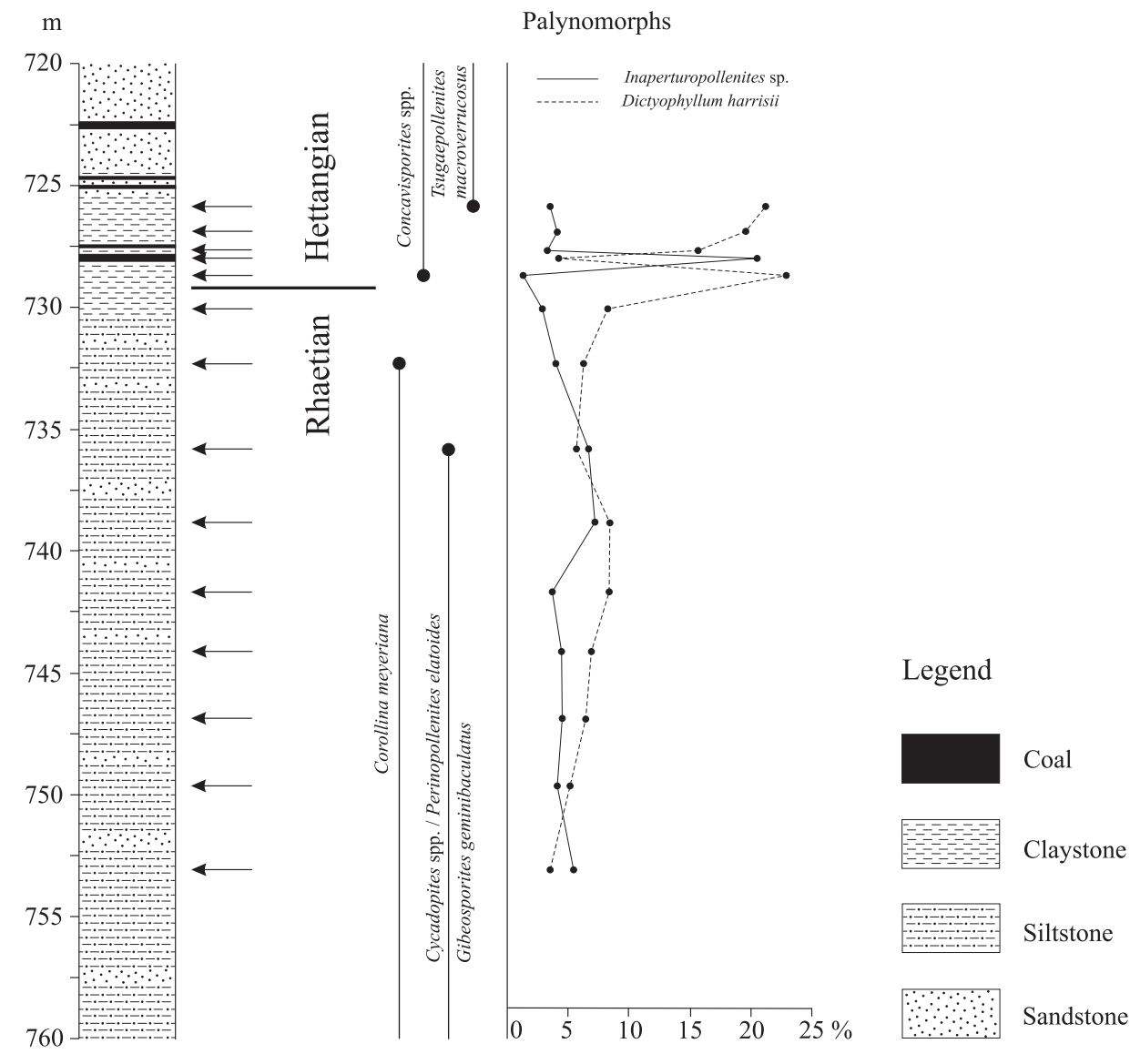

Fig. 3

Distribution of palynomorphs of the Triassic/Jurassic boundary interval, Komló borehole K-176, Mecsek Mts. (South Hungary). Note the sudden increase of Dictyophyllum harrisii at the Triassic/Jurassic boundary, followed by peak abundance of Inaperturopollenites sp. within the first coal layer 
Palynology of a terrestrial coal-bearing series across the Triassic/Jurassic boundary (Hungary) 7

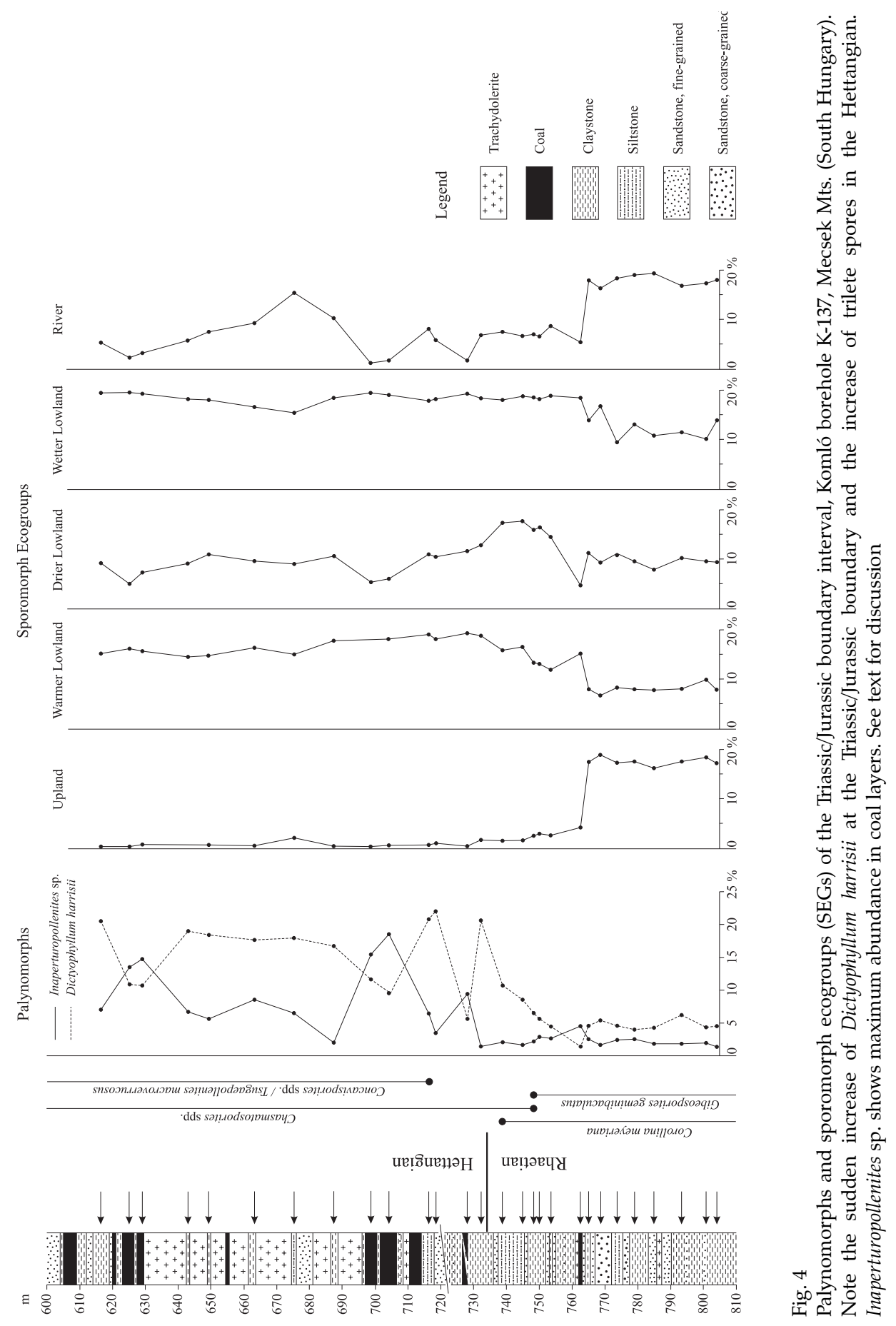

Central European Geology 51, 2008 

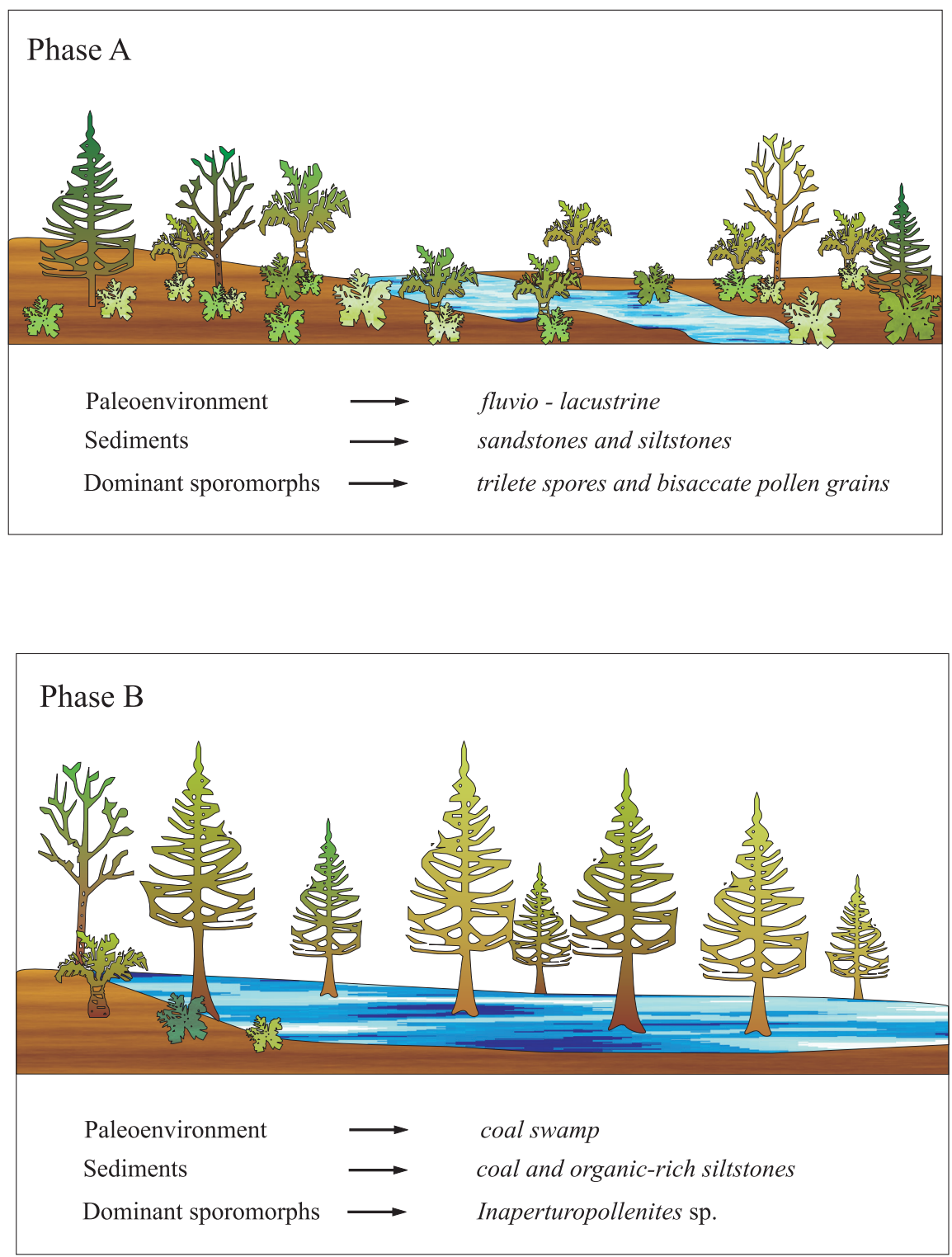

Fig. 5

Reconstruction of vegetation patterns in the Triassic/Jurassic boundary interval as inferred from palynomorph associations. Cyclic short-term paleoenvironmental changes from fluvial/deltaic to swamp settings are documented in two characteristic palynomorph assemblages with dominance of trilete spores and bisaccate pollen grains and Inaperturopollenites sp., respectively 


\section{Application of the Sporomorph Ecogroup Model}

In order to define sporomorph ecogroups for the Mesozoic and to model the response of these groups to paleoenvironmental change, the establishment of an ecological framework for the source communities is necessary. According to Grime (1979), two factors determine the type of plants defining a specific vegetation: stress and disturbance. The variation of the level of stress and disturbance results in three different plant strategies: a competitive strategy (low stress, low disturbance), a stress-tolerating strategy (high stress, low disturbance), and a ruderal strategy (low stress, high disturbance), whereas highly disturbed habitats with severe and continuous stress are not viable as plant habitats. Following this concept, Abbink et al. (2001) established six sporomorph ecogroups (SEGs) for the Late Jurassic-Early Cretaceous of NW Europe (Table 1). The Lowland SEG reflects the vegetation present in the main lowland area. The lowland represents an area with an optimum of nutrients and fresh water, low stress and low disturbance. The lowland plants follow a competitive strategy; consequently the ecological boundaries of the plants reflected by this SEG are determined by less than optimum conditions surrounding this lowland area. The plants within the communities reflected by other SEGs will follow a stresstolerating or ruderal strategy. Seaward, ecological stress is introduced by the influence of salt water in a tidally influenced area and salt spray in a coastal area. Landward, the possible deficiency of nutrients and/or the decreased availability of fresh water in the upland area may introduce ecological stress. Along rivers, periodical submersion and erosion of riverbanks will cause plants to follow a more ruderal strategy. A ruderal strategy will also be employed by first colonizers or pioneer plants. As for plants in the lowland area, the plants within the other ecologically defined areas will also show a competitive strategy, as they are optimized for the ecology of that particular habitat (Abbink et al. 2001).

However, the general grouping of fossil pollen grains and spores into different ecogroups remains difficult. First the SEG model was created for the Upper Jurassic-Lower Cretaceous of the North Sea and it must be taken into account that the climatic conditions during this period differed from those at the Triassic/Jurassic boundary. "Drier" intervals in the Cretaceous climate were probably still wetter than a wet climate during the Hettangian. Therefore, the warmer/cooler and wetter/drier trends are not applicable for Triassic/Jurassic boundary palynomorph assemblages. Second, the parent plants for many Mesozoic sporomorphs are still unknown. Therefore, the SEG model is incomplete and many classifications are only based on morphological features. Third, the tolerance of many plant genera with respect to stress and disturbance is not well understood. Therefore, many plants could be indicators of different environments, e.g. river and lowland (Abbink et al. 2004b). Thus, some of the sporomorph taxa of this study have been re-grouped with respect to the different conditions at the Triassic/Jurassic boundary: Spore genera such as Concavisporites and Deltoidospora have been transferred from the "drier" lowland SEG to the 
"wetter" lowland and "river" SEG, and palynomorphs encountered in the studied cores were assigned to five SEGs (Table 2), reflecting the environmental conditions of the depositional area. In the Komlo core sections the Rhaetian palynomorph assemblages are characterized by pollen grains and spores of the "upland" and "river" SEGs (Fig. 4). Due to the terrestrial setting, the "coastal" SEG is hardly represented and not taken into account here. In the upper (i.e. lowermost Hettangian) part of the section, the "warmer lowland" and "drier lowland" SEGs defined by Abbink et al. (2001) dominate the assemblage. On the basis of the re-grouping described above, "wetter lowland" sporomorphs predominate, accompanied by "river" SEG indicators (Fig. 4).

\section{Discussion}

Palynomorph assemblages of the Komló sections display a typical Rhaetian/Hettangian microflora, dominated by bisaccate pollen grains, trilete spores and pollen of the Circumpolles group. The high amount of phytoclasts clearly documents the diverse land plant community which is well known from macrophyte findings of the Mecsek Coal (e.g. Barbacka 2000, 2001, 2002). The occurrence of Corollina spp. in the Upper Rhaetian part of the series points to relatively temperate climatic conditions (cf. Vakhrameev 1981). The increase of trilete spores within the Triassic/Jurassic boundary interval is interpreted to indicate an increase of humidity. This agrees with geochemical evidence of increased weathering at the Triassic/Jurassic boundary (Cohen and Coe 2002, 2007). This global paleoclimatic signal is superimposed by a regional paleoenvironmental change from fluvial to swamp conditions as documented by the two microfloral assemblages that are related to different paleoenvironments (Fig. 5).

The cyclicity revealed by our palynological results is compatible with, but significantly extends, the model of Bóna (1963), who only analyzed the coal seams and recognized that superjacent parts of individual seams differ in their palynomorph content. Consistently, the lower coal layer was interpreted as deposited in a shallow swamp forest zone, overlain by a coal layer formed in a deeper swamp. An early sedimentological study of the coal-bearing sequence also documented cyclic changes in the depositional environments (Káli 1962).

No mass extinction event is apparent in the studied material from the Mecsek Mountains, which agrees with the macrofloral data of the Mecsek Coal Formation (Barbacka, pers. comm., 2008) and other Triassic/Jurassic boundary key sections of the NW Tethyan realm (Ruckwied 2008; Ruckwied and Götz 2008). Palynomorph assemblages of the Komló sections are similar to the assemblages of the Germanic Basin (cf. Schulz 1967; Orlowska-Zwolińska 1983; Weiss 1989; Lund 1977; 2003) comprising marker species such as Rhaetipollis germanicus and a high amount of Classopollis spp. in the Upper Rhaetian part of the section. The Hettangian marker species Cerebropollenites thiergartii, reported by Kuerschner et al. (2007) and von Hillebrandt et al. (2007) from the Northern Calcareous Alps, is 
Palynology of a terrestrial coal-bearing series across the Triassic/Jurassic boundary (Hungary) 11

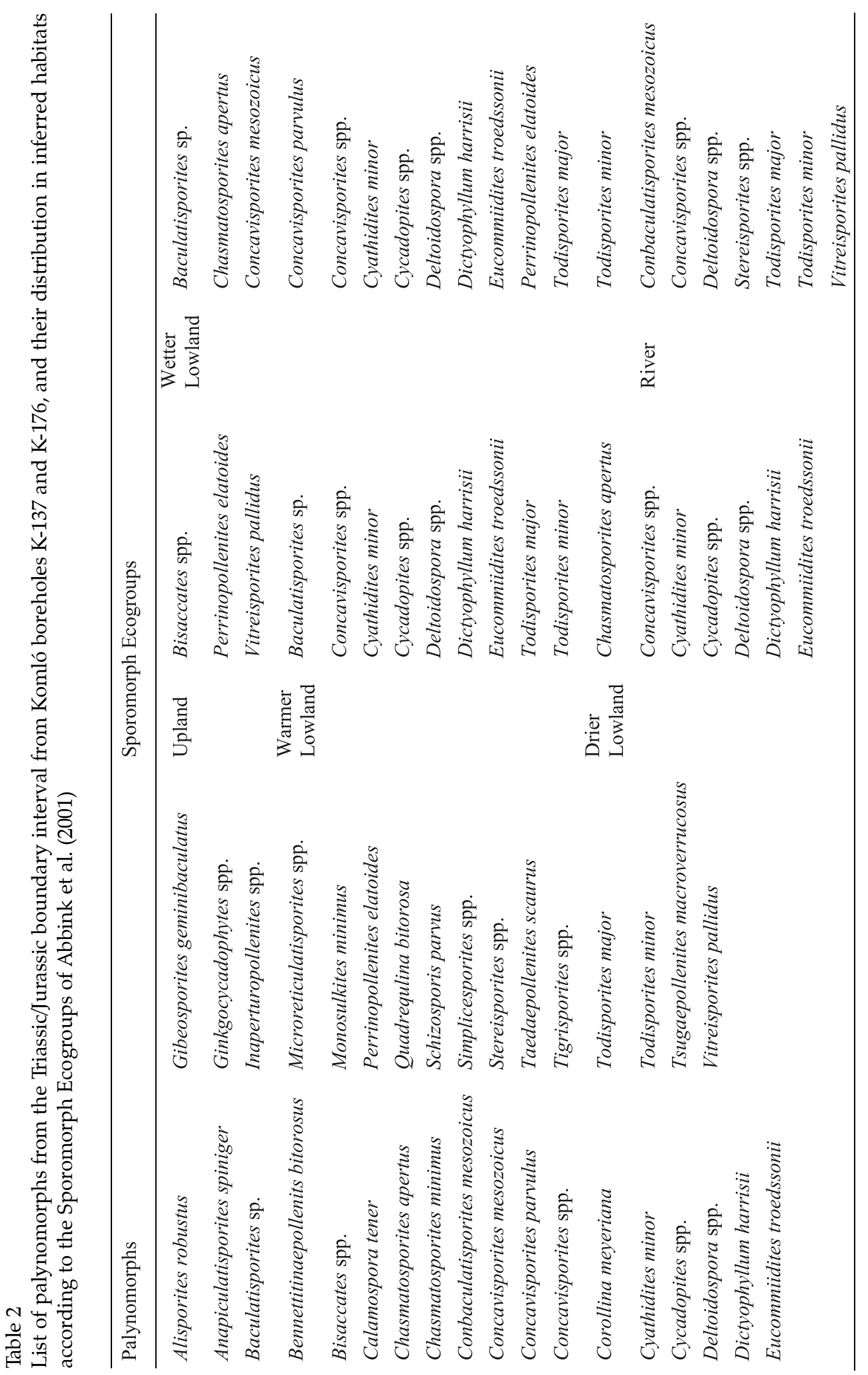

Central European Geology 51, 2008 
absent in the Mecsek Mountains. This may be attributed either to the lack of the mother plant in the Mecsek vegetation or to its low abundance. However, in the Alpine sections the lowest occurrence of this pollen grain is proposed as a potential palynological marker for the Triassic/Jurassic boundary.

The most striking feature within the boundary interval is the regional paleoenvironmental change of river/deltaic to swamp settings in short-term cyclic patterns, as inferred from changes in palynomorph associations. However, increasing humidity is documented by a striking increase in trilete spores and likely reflects a global climatic signal. Both signatures display the response of terrestrial vegetation to regional and global environmental changes.

\section{Conclusions}

The palynological material studied from the Komló boreholes clearly documents changes at the Triassic/Jurassic boundary which are related to both regional changes in paleoenvironment and global climatic change. An isolated study of microfloral assemblages is not sufficient to clarify the major causes of such drastic changes. Ongoing studies will therefore focus on both palynomorphs and macrophytes to further analyze vegetation patterns and their changes across the Triassic/Jurassic boundary. Furthermore, these studies will contribute to verifying the definition and applicability of sporomorph ecogroups (SEGs) in early Mesozoic terrestrial settings.

No evidence of a mass extinction event was detected in the studied material, although our observations suggest significant environmental changes reflected in the palynomorph assemblage. These changes are interpreted to document both regional vegetation patterns and globally increasing humidity. The interpretation of changes within terrestrial vegetation patterns and the role of floral change associated with mass extinction events remains difficult. Therefore, integrated studies of land plant communities and their vegetation dynamics within a recovery phase of a stressed ecosystem during the earliest Jurassic (Hettangian), recorded in changes of palynomorph and macrophyte assemblages of the Mecsek Coal Formation, are seen as crucial to a better understanding of terrestrial ecosystems.

\section{Acknowledgements}

This study is part of a project on microfloral changes within the Triassic/Jurassic boundary interval of key sections of the NW Tethyan realm (Hungary, Slovakia) supported by the German Research Foundation (DFG project GO 761/2-1). Additional financial support was provided by the Hungarian Scientific Research Fund (OTKA T42802) and an EU-funded SYNTHESYS grant to A.E.G. We thank J. Bóna and M. Sütő-Szentai for making available palynological slides kept at the Komló Natural History Collections, and L. Kordos (Hungarian Geological 
Institute) for permission to sample the core K-137 at the Pécs-Vasas Core Repository. We also acknowledge the very constructive reviews of M. Barbacka (Hungarian Natural History Museum) and J. Haas (Eötvös Loránd University). This is MTA-MTM Paleo contribution No. 73.

\section{References}

Abbink, O.A., J. Targaron, H. Brinkhuis, H. Visscher 2001: Late Jurassic to earliest Cretaceous paleoclimatic evolution of the southern North Sea. - Global and Planetary Change, 30, pp. 231-256.

Abbink, O.A., J.H.A. Van Konijnenburg-Van Cittert, H. Visscher 2004a: A sporomorph ecogroup model of the Northwest European Jurassic-Lower Cretaceous: concepts and framework. Geologie en Mijnbouw, 83, pp. 17-38.

Abbink, O.A., J.H.A. Van Konijnenburg-Van Cittert, H. Visscher 2004b: A sporomorph ecogroup model of the Northwest European Jurassic - Lower Cretaceous II: application to an exploration well from the Dutch North Sea. - Netherlands Journal of Geosciences, 83, pp. 81-92.

Barbacka, M. 2000: Bennettitales from the Mecsek Mountains Liassic, Hungary. - Acta Palaeobotanica, 40, pp. 111-127.

Barbacka M. 2001: The cycads of Hungarian Liassic. - Revue de Paléobiologie, 20, pp. 525-541.

Barbacka, M. 2002: The Liassic Ginkgoales from the Mecsek Mountains, Hungary. - Revue de Paléobiologie, 21, pp. 697-715.

Bleahu, M., Gh. Mantea, S. Bordea, St. Panin, M. Stefanescu, K. Sikic, S. Kovács, Cs. Péró, J. Haas, A. Bérczi-Makk, E. Nagy, Gy. Konrád, E. Rálisch-Felgenhauer, Á. Török 1994: Triassic facies types, evolution and paleogeographic relations of the Tisza Megaunit. - Acta Geologica Hungarica, 37, pp. 187-234.

Bóna, J. 1963: Palynologische Untersuchungen zwecks einer Feinkorrelierung der liassischen Steinkohleflöze des Mecsek-Gebirges. - Földtani Közlöny, 93, pp. 15-23. (In Hungarian with German abstract.)

Bóna, J. 1969: Palynologie. - In: Nagy, E. (Ed.): Unterlias-Kohlenserie des Mecsek-Gebirges. Geologie. - Annals of the Hungarian Geological Institute, 51, pp. 623-707. (In Hungarian with German summary.)

Bóna, J. 1979: Tele-identification of coal seam groups by palynological methods within the Mecsek Lower Liassic Coal Measures. - Földtani Kutatás, 22, pp. 29-32. (In Hungarian.)

Bóna, J. 1983: Palynological studies on the Upper Triassic and Lower Liassic of the Mecsek Mountains. - Őslénytani Viták, 29, pp. 47-57. (In Hungarian with English abstract.)

Bóna, J. 1995a: Palynostratigraphy of the Upper Triassic formations in the Mecsek Mts. (Southern Hungary). - Acta Geologica Hungarica, 38, pp. 319-354.

Bóna, J. 1995b: A Mecseki Kőszén Formáció palynológiai vizsgálati eredményeinek összefoglalása (Results of the palynological investigation of the Mecsek Black-Coal Formation). - In: Z. Némedi Varga (Ed.): A mecseki feketekőszén kutatása és bányaföldtana (Research and Mining Geology of the Black-Coal Deposit in the Mecsek Mountains). - Miskolci Egyetem (University of Miskolc), Miskolc, pp. 261-281.

Cohen, A.S., A.L. Coe 2002: New geochemical evidence for the onset of volcanism in the Central Atlantic magmatic province and environmental change at the Triassic-Jurassic boundary. Geology, 30, pp. 267-270.

Cohen, A.S., A.L. Coe 2007: The impact of the Central Atlantic Magmatic Province on climate and on the Sr- and Os-isotope evolution of seawater. - Palaeogeography, Palaeoclimatology, Palaeoecology, 244, pp. 374-390.

Grime, J.P. 1979: Plant Strategies and Vegetation Processes. - John Wiley, Chichester, 222 p. 
Haas, J. 2004: Characteristics of peritidal facies and evidences for subaerial exposures in Dachsteintype cyclic platform carbonates in the Transdanubian Range, Hungary. - Facies, 50, pp. 263-286.

Haas, J., Á. Török 2008: Hungary. - In: Feist-Burkhardt, S., A.E. Götz, J. Szulc (coordinators), R. Borkhataria, M. Geluk, J. Haas, J. Hornung, P. Jordan, O. Kempf, J. Michalík, J. Nawrocki, L. Reinhardt, W. Ricken, G.-H. Röhling, T. Rüffer, Á. Török, R. Zühlke: Triassic. - In: McCann, T (Ed.): The Geology of Central Europe. Geological Society, London.

Hornung, J., R. Ashraf, M. Yuyan, L. Jie, G. Sun, V. Mosbrugger, M. Hinderer 2007: Sedimentary analysis of a lacustrine to fluvial environment and its depositional dynamics (Haojiagou-valley, Junggar-Basin, NW-China). In: Sun, G., V. Mosbrugger, Y.W. Sun, A. Bruch (Eds): Proceedings of the International Symposium for Sino-German Cooperation on Geology and Environmental Changes in Northern China. Urumqi, China, pp. 65-73.

Káli, Z. 1962: Üledékciklusosság a mecseki alsó liász kőszéntelepes összletben. Komlói terület [Sedimentary cyclicity in the Lower Liassic coal-bearing series of the Mecsek, Komló district]. Földtani Kutatás, 5, pp. 12-40. (In Hungarian.)

Kuerschner, W. M., N.R. Bonis, L. Krystyn 2007: Carbon-isotope stratigraphy and palynostratigraphy of the Triassic-Jurassic transition in the Tiefengraben section - Northern Calcareous Alps (Austria). - Palaeogeography, Palaeoclimatology, Palaeoecology, 244, pp. 257-280.

Lund, J.J. 1977: Rhaetic and Lower Liassic palynology of the onshore south-eastern North Sea Basin. - Danmarks Geologiske Undersogelse, Ser. 1, 109, pp. 1-103.

Lund, J.J. 2003: Rhaetian to Pliensbachian palynostratigraphy of the central part of the NW German Basin exemplified by the Eitzendorf 8 well. - Courier Forschungsinstitut Senckenberg, 241, pp. 69-83.

McElwain, J.C., M.E. Popa, S.P. Hesselbo, M. Haworth, F. Surlyk 2007: Macroecological responses of terrestrial vegetation to climatic and atmospheric change across the Triassic/Jurassic boundary in East Greenland. - Paleobiology, 33, pp. 547-573.

McElwain, J.C., S.W. Punyasena 2007: Mass extinction events and the plant fossil record. - Trends in Ecology and Evolution, 22, pp. 548-557.

Nagy, E. 1968: A Mecsek hegység triászidőszaki képződményei (The Triassic of Mecsek Mountains). - Annals of the Hungarian Geological Institute, 51, 1, 198 p. (In Hungarian with German abstract.)

Nagy, E. 1971: Der unterliassische Schichtenkomplex von Grestener Fazies im Mecsek-Gebirge (Ungarn). - Annals of the Hungarian Geological Institute, 54/2, pp. 155-159. (In Hungarian with German abstract.)

Nagy, E., J. Nagy 1969: Rétegtan (Stratigraphie). - In: E. Nagy (Ed.): A Mecsek hegység alsóliász kőszénösszlete (földtan) [Unterlias-Kohlenserie des Mecsek-Gebirges (Geologie)]. - Annals of the Hungarian Geological Institute 51/2, pp. 625-707.

Némedi Varga, Z. (Ed.) 1995: A mecseki feketekôszén kutatása és bányaföldtana (Research and Mining Geology of the Black-Coal Deposit in the Mecsek Mountains). Miskolci Egyetem (University of Miskolc), Miskolc, $472 \mathrm{p}$.

Némedi Varga, Z. 1983: Parallelisierungsmöglichkeiten innerhalb der Mecseker Steinkohlformation. - Publications of Technical University of Heavy Industry, Miskolc, ser. A, 38, pp. 75-97.

Olsen, P.E., C. Koeberl, H. Huber, A. Montanari, S.J. Fowell, M. Et Touhami, D.V. Kent. 2002: The continental Triassic-Jurassic boundary in central Pangaea: recent progress and discussion of an Ir anomaly. - GSA Special Paper, 356, pp. 505-522.

Orłowska-Zwolińska, T. 1983: Palinostratygrafia epikontynentalnych osadów wyzszego triasu w Polsce. - Prace Instytutu Geologicznego, 104, pp. 1-88.

Ruckwied, K. 2008: Palynology of Triassic/Jurassic boundary key sections of the NW Tethyan Realm (Hungary and Slovakia). - Ph.D. Thesis, Darmstadt University of Technology, 85 p.

Ruckwied, K., A.E. Götz 2008: Climate change at the Triassic/Jurassic boundary: palynological evidence from the Furkaska section (Tatra Mts., Slovakia). - Geologica Carpathica (Submitted.) 
Schulz, E. 1967: Sporenpaläontologische Untersuchungen rätoliassischer Schichten im Zentralteil des Germanischen Beckens. - Paläontologische Abhandlungen, B 2, pp. 541-633.

Steffen, D., G.E. Gorin 1993: Palynofacies of the Upper Tithonian-Berriasian deep-sea carbonates in the Vocontian Trough (SE France). - Bulletin des Centres de Recherches Exploration-Production Elf-Aquitaine, 17, pp. 235-247.

von Hillebrandt, A., L. Krystyn, W.M. Kuerschner with contributions by P.R. Bown, C. McRoberts, M. Ruhl, M. Simms, A. Tomasovych, M. Urlichs 2007: A candidate GSSP for the base of the Jurassic in the Northern Calcareous Alps (Kuhjoch section, Karwendel Mountains, Tyrol, Austria). - In: Bown, P.R., N. Morton, J. Lees (Eds): International Subcommission on Jurassic Stratigraphy Newsletter, 34, pp. 2-20.

Vakhrameev, V.A. 1981: Pollen Classopollis: indicator of Jurassic and Cretaceous climates. - The Palaeobotanist, 28/29, pp. 301-307.

Voigt, S., H. Haubold, S. Meng, D. Krause, J. Buchantschenko, K. Ruckwied, A.E. Götz 2006: Die Fossil-Lagerstätte Madygen: Ein Beitrag zur Geologie und Paläontologie der MadygenFormation (Mittel- bis Ober-Trias, SW-Kirgisistan, Zentralasien). - Hallesches Jahrbuch für Geowissenschaften, Beiheft 22, pp. 85-119.

Weiss, M. 1989: Die Sporenfloren aus Rhät und Jura Süddeutschlands und ihre Beziehungen zur Ammoniten-Stratigraphie. - Palaeontographica, B 215, pp. 1-168. 